\title{
Pergerakan Sosial Perempuan Pesisir dalam Memperjuangkan Hak Asasi Manusia dan Kesetaraan Gender
}

\author{
Ratna Indrawasiha,1, Lengga Pradiptab,2* \\ a Puslit Masyarakat dan Budaya, LIPI, Jalan Jend. Gatot Subroto No. 10 Jakarta Selatan 12710, Indonesia \\ b Puslit Kependudukan, LIPI, Jalan Jend. Gatot Subroto No. 10 Jakarta Selatan 12710, Indonesia \\ ${ }^{1}$ ratnapmb@yahoo.co.id; ${ }^{2}$ lengga.pradipta@gmail.com \\ * Corresponding Author
}

\begin{tabular}{ll}
\hline INFO ARTIKEL & ABSTRAK \\
\hline Sejarah Artikel: & Komunitas pesisir di Indonesia sangat rentan dengan kemiskinan. Untuk \\
Diterima: 9 Februari 2021 & mengatasi kemiskinan, kontribusi dari laki laki dan perempuan sangat \\
Direvisi: 9 Maret 2021 & dibutuhkan. Menurut data terkini, terdapat 2.7 juta nelayan di Indonesia \\
Disetujui: 24 Maret 2021 & dan mayoritas berada di garis kemiskinan. Nelayan yang masuk dalam \\
Tersedia Daring: 10 April 2021 & kategori ini bukan hanya nelayan laki-laki, namun juga nelayan \\
\hline Kata Kunci: & perempuan. Berbicara mengenai nelayan, laki-laki selalumenjadi sentra \\
Hak Asasi Manusia & utama dalam kegiatan perikanan. Namun pada kenyatannya, di \\
Kesetaraan Gender & beberapa daerah di Indonesia, kaum perempuan cenderung memiliki \\
Perempuan Pesisir & peranan lebih signifikan dibanding laki-laki, baik di area domestik \\
& maupun pada kegiatan produktif yang berhubungan dengan perikanan. \\
& Artikel ini bertujuan untuk menganalisa keterlibatan serta peran \\
& perempuan pesisir dalam memenuhi kebutuhan hidup keluarganya \\
& serta memberikan pemahaman mengenai kondisi serta pergerakan \\
& sosial perempuan pesisir Demak, agar keberadaan mereka diakui oleh \\
& pemerintah. Artikel ini dibuat berdasarkan hasil penelitian di Kabupaten \\
& Demak dengan menggunakan metode kualitatif melalui pengumpulan \\
& data primer (ke lapangan) dan analisa data sekunder. Hasil yang \\
& diperoleh melalui penelitian ini menggambarkan bahwa perempuan \\
nelayan di Kabupaten Demak telah menyadari bahwa mereka harus & melakukan pergerakan sosial agar bisa memperjuangkan hak dan \\
kesetaraan mereka sebagai subjek hukum yang diakui oleh negara & karena melalui pergerakan tersebut barulah mereka bisa mengakses \\
& segala program peningkatan kapasitas yang bermanfaat untuk \\
& pengurangan kemiskinan.
\end{tabular}

\begin{tabular}{ll}
\hline ABSTRACT \\
\hline Keywords: & In Indonesian coastal communities, poverty is becoming one of the major \\
Human Rights & issue. To eradicate poverty, there should be a significant contribution from \\
Gender Equality & male and female. According to the latest data, there are 2.7 million \\
Coastal Women & fishermen in Indonesia who trapped in poverty. Fishermen who included \\
Cosial Movement & fishermen, male have always been the main centers in fishing activities. \\
But in fact, in some regions in Indonesia, women have more significant role \\
than men, both in the domestic area and in productive activities. This \\
article aims to analyze the involvement of coastal women in fulfilling their \\
family needs as well as to give such understanding about their vivid \\
condition in conducting social movement, so that their existence will be \\
acknowledged by government. This article is based on field research \\
conducted in Demak regency using qualitative methods, such as data \\
collected from primary and secondary sources. The result of this research \\
elucidates that fisherwomen in Demak has realized that they need to \\
conduct social movement to fight for the rights and equalities as the legal
\end{tabular}


subject of a state, because through that movement, then they might access the capacity building program which can eradicate their poverty level.

(C) 2021, Indrawasih \& Pradipta

This is an open access article under CC-BY license

How to Cite: Indrawasih, R., \& Pradipta, L. (2021). Pergerakan Sosial Perempuan Pesisir dalam Memperjuangkan Hak Asasi Manusia dan Kesetaraan Gender. Satwika : Kajian Ilmu Budaya dan Perubahan Sosial, 5 (1), 105-117. doi: 10.22219/satwika.v5i1.15537

\section{Pendahuluan}

Indonesia merupakan salah satu negara maritim terbesar di dunia dengan garis pantai sepanjang $\pm 95,181 \mathrm{~km}^{2}$ dan luas wilayah laut mencapai 5,8 juta $\mathrm{km}^{2}$. Dengan panjang garis pantai dan luas wilayah laut tersebut, kekayaan maritim dan pesisir Indonesia menjadi sangat besar dan beragam. Menurut data Koalisi Rakyat Untuk Keadilan Perikanan (2017), terdapat 12.827 desa pesisir di Indonesia yang dihuni oleh lebih dari 8.1 juta rumah tangga pesisir. Sebagai masyarakat pesisir, mayoritas menggantungkan hidupnya pada sektor perikanan, baik sebagai nelayan ataupun pembudidaya. Data terbaru dari Kementerian Kelautan dan Perikanan Republik Indonesia memperlihatkan bahwa jumlah nelayan pada tahun 2019 mencapai 2.7 juta orang. Mayoritas masih berada di ambang batas garis kemiskinan dan berkontribusi sebanyak 25 persen terhadap angka kemiskinan nasional (Kementerian Kelautan dan Perikanan, 2019).

Dalam komunitas pesisir Indonesia, peranan laki-laki dan perempuan sama pentingnya. Bahkan di beberapa daerah, kaum perempuan cenderung memiliki peranan lebih besar, baik di ranah domestik maupun pada aktivitas produktif, yaitu sebagai pencari nafkah (breadwinner). Dalam kajian yang dilakukan oleh Pratiwi dan Boangmanalu (2017) disebutkan bahwa keterlibatan perempuan pesisir dalam aktivitas produktif tersebut didorong keinginan mereka untuk memenuhi kebutuhan hidup keluarganya. Fenomena perempuan sebagai pencari nafkah tidak terjadi di satu daerah pesisir saja, namun hampir di seluruh wilayah pesisir Indonesia (Adhuri et. al, 2018).

Besarnya keterlibatan perempuan pesisir dalam kegiatan produktif (ekonomi) seringkali tidak dianggap sebagai kontribusi utama dalam keluarga, melainkan hanya sebagai pelengkap atau sampingan untuk membantu suaminya sebagai nelayan. Hal seperti ini bahkan turut serta dilegitimasi oleh masyarakat dan budaya, yang menyatakan bahwa perempuan pesisir hanyalah "pelengkap" bagi suaminya yang bekerja sebagai nelayan. Padahal menurut kajian Indrawasih (2015) serta Adhuri et. al. (2018), perempuan pesisir berperan sangat signifikan mulai dari membantu persiapan suami melaut (dengan menyiapkan bekal), ikut serta mencari atau menangkap ikan di laut (menjadi nelayan), memasarkan hasil tangkapan ikan, sampai pada mengolah hasil tangkapan ikan.

Di beberapa wilayah pesisir Indonesia, seperti Langkat, Dipasena, Demak, Lombok dan Selayar, perempuan pesisir memiliki kontribusi yang beragam. Menurut kajian yang dilakukan oleh Adhuri et. al. (2018), perempuan pesisir merupakan sosok tangguh yang terlibat dalam hampir semua kegiatan pesisir, seperti proses pembudidayaan silvofishery (sistem pembudidayaan ikan tradisional berupa tambak yang menggabungkan antara usaha perikanan dengan penanaman mangrove), tambak udang, penangkapan ikan ke laut lepas, terlibat dalam pembuatan kebijakan adat mengenai penangkapan ikan, sampai pada pengelolaan sampah di wilayah pesisir. 
Seperti di daerah pesisir Jawa, perempuan banyak yang menjadi tulang punggung keluarga, bahkan mempunyai kewajiban untuk menanggung beban kemiskinan sosial. Data dari Persaudaraan Perempuan Nelayan Indonesia (PPNI) menyebutkan bahwa perempuan pesisir yang juga berprofesi sebagai nelayan dan memiliki status termarginalkan, perlu diberdayakan dan diberikan kapasitas agar tidak semakin rentan akan kemiskinan (Persaudaraan Perempuan Nelayan Indonesia, 2018). Karena dengan memberdayakan dan membangun kapasitas perempuan pesisir, maka mereka akan memiliki akses terhadap fasilitas publik, bantuan sosial, serta memiliki hak sebagai seorang warga negara yang legal secara hukum dan peraturan perundangan.

Permasalahan mengenai perempuan pesisir yang telah bertransformasi menjadi perempuan nelayan belum mendapat perhatian maksimal dari pemerintah dan masyarakat. Kajian-kajian mengenai nelayan selama ini hanya memprioritaskan masalah kemiskinan semata dan masih bias gender (berfokus pada peranan nelayan lakilaki saja). Padahal, di banyak wilayah pesisir, khususnya di wilayah Demak, Jawa Tengah, dalam 5 tahun belakangan ini, perempuan ikut terlibat langsung dalam kegiatan penangkapan ikan di laut lepas. Hal inilah yang kemudian menjadi concern utama dalam penelitian ini, yaitu untuk melihat dan menyajikan data dan fakta bahwa keterlibatan perempuan di wilayah pesisir sangat besar, dan justru merekalah yang banyak melakukan pergerakan sosial untuk mengatasi kemiskinan baik di tingkat rumah tangga maupun masyarakat.

Seperti contoh, perempuan pesisir di Demak ikut serta melaut dengan suaminya. Mereka merasakan kondisi ombak, gelombang dan badai di tengah laut yang tidak bisa diprediksi. Dengan tingginya risiko yang dihadapi perempuan tersebut, seharusnya mereka mendapat pengakuan sebagai "perempuan nelayan", bukan hanya sebagai perempuan yang "menunjang" aktivitas melaut suaminya. Puspitasari
(2012) menyebutkan bahwa perempuan memiliki kapasitas mental dan sosial, serta motivasi yang kuat untuk membantu perekonomian keluarga. Ditambahkan juga oleh Widhyharto (2015), kaum perempuan merupakan agent of change dalam mengurangi tingkat kemiskinan, baik dalam lingkup keluarga, komunitas, bahkan negara. Selain itu, mencuatnya fakta tentang belum diakuinya perempuan sebagai "nelayan" pada kartu identitasnya (Kartu Tanda Penduduk) menimbulkan konflik baru. Perempuan kerap dipandang sebelah mata dan haknya belum diberikan sepenuhnya sebagai subjek hukum. Padahal, hak dan kesetaraan yang ingin diperjuangkan perempuan pesisir tersebut menjadi kunci untuk bisa mengakses fasilitas, program pemberdayaan atau pelatihan, serta program bantuan sosial yang diberikan oleh negara serta pemerintah (Adhuri et. al., 2018). Kenyataan inilah yang kemudian menyebabkan perempuan pesisir melakukan pergerakan sosial agar hak mereka menjadi sejajar, sesuai dengan peranan dan fungsi nyata mereka di dalam keluarga dan komunitasnya.

Untuk mengurai semua permasalahan itu, maka artikel ini berfokus pada penjelasan tentang kondisi perempuan pesisir Demak, serta pergerakan yang mereka lakukan agar diakui sebagai "perempuan nelayan" oleh pemerintah.

\section{Metode}

Penelitian ini menggunakan metodologi kualitatif dengan menitikberatkan pada observasi, korelasi, serta interaksi antarmanusia. Menurut Pathak et.al. (2013), metode kualitatif sangat penting untuk mengetahui perspektif, pengalaman, perilaku serta interaksi manusia. Walaupun tidak menggunakan data berupa angka, namun metode ini mampu menjadi strategi jitu dalam mengungkapkan fenomena sosial di masyarakat. Selain itu, penelitian yang menggunakan metode kualitatif akan memberikan dimensi baru jika peneliti juga melakukan pengamatan disertai intervensi yang bertujuan untuk memberikan solusi 
kebijakan yang terintegrasi bagi masyarakat (Gibson et. al, 2004).

Data yang digunakan untuk penulisan artikel ini berasal dari data kegiatan penelitian Prioritas Nasional yang berjudul Peningkatan Kesejahteran Nelayan Dengan Pendekatan Holistik dan Kolaboratif: Lima Kasus Uji Coba Pengentasan Kemiskinan. Pada di artikel ini dititikberatkan pada permasalah perempuan pesisir di Kabupaten Demak, Jawa Tengah. Penelitian dilakukan selama medio 2018 sampai 2019, tepatnya di Kecamatan Bonang, Kabupaten Demak. Lokasi ini sengaja dipilih karena banyaknya nelayan perempuan yang aktif melakukan kegiatan melaut dan juga aktif terlibat dalam kegiatan pergerakan sosial.

Pengumpulan data dalam penelitian ini dilakukan melalui 2 cara, yaitu melalui data primer (data yang diperoleh dari kegiatan lapangan) dan juga melalui data sekunder (analisa literatur, analisa kebijakan pemerintah, serta sumber-sumber lainnya). Data primer diperoleh dengan cara melakukan kegiatan diagnosis (participatory diagnosis), yaitu mengidentifikasi potensi, tantangan serta opsi-opsi pengelolaan pesisir atau perikanan. Selain itu, fungsi dan peranan informan kunci menjadi sangat penting dalam penelitian ini. Sebanyak 8 orang informan kunci yang notabene merupakan perempuan nelayan dilibatkan dalam penelitian ini, tujuannya agar bisa menggali semua data dan juga memberikan informasi terkait penelitian.

Dalam tahap menggali informasi dari informan kunci dan juga melakukan diagnosis penelitian, metode Fish Collab dari Ross et. al. (2018) digunakan sebagai dasar pijakan. Hal ini dikarenakan sangat penting untuk menggali sisi grassroot (akar rumput) maupun dari sisi governance (tata kelola di pemerintahan). Pendekatan ini diharapkan dapat menjembatani pemerintah, komunitas, akademisi, organisasi masyarakat sipil atau LSM, serta pihak lain untuk dapat saling terkoneksi dalam mengentaskan kemiskinan dan menyejahterakan nelayan sebelum membuat rencana pembangunan nasional yang terintegrasi untuk sektor perikanan. Dalam participatory diagnosis ini, kegiatan FGD (diskusi kelompok terarah) menjadi sangat penting karena melibatkan semua nelayan (baik laki-laki maupun perempuan), petambak, perempuan pengolah hasil ikan, perempuan penjual ikan (bakulan ikan), tokoh LSM perempuan "Puspita Bahari", aparat desa, sampai ke dinas terkait di Pemerintahan Kabupaten Demak. Selain itu, observasi dan wawancara mendalam juga sangat diperlukan untuk menggali data lebih mendalam.

Selanjutnya, data sekunder diperoleh melalui kajian literatur, analisa kebijakan pemerintah serta peraturan hukum lainnya (baik daerah maupun nasional). Data yang sudah didapat kemudian dikelompokkan dan disajikan dalam bentuk narasi menggunakan analisa deskriptif interpretatif. Selain itu, kerangka hak asasi manusia serta kesetaraan gender digunakan sebagai perspektif yang melandasi analisis dalam penelitian ini.

\section{Hasil dan Pembahasan}

Pada bagian hasil dan pembahasan dijelaskan secara rinci tentang kondisi geografis dan demografis Kabupaten Demak, kondisi perempuan pesisir di Kabupaten Demak dalam memperjuangkan HAM dan kesetaraan gender untuk mendapatkan pengakuan sebagai nelayan akan dibahas pada bagian ini.

\subsection{Kondisi Geografis dan Demografis Kabupaten Demak}

Demak merupakan salah satu wilayah administratif kabupaten yang terletak di Provinsi Jawa Tengah. Di kabupaten ini terdapat kecamatan yang menjadi sentra industri perikanan, yaitu Kecamatan Bonang. Di wilayah ini terdapat hutan mangrove yang berjarak sekitar $3 \mathrm{~km}$ dari garis pantai, dan meliputi hampir seluruh wilayah, seperti Desa Betahwalang, Desa Gebang, Desa Margolinduk, Desa Morodemak, Desa Purworejo, serta Desa Tridonorejo. Di Kecamatan Bonang terdapat hutan mangrove seluas 209,17 Ha. Dari 
besarnya luasan hutan mangrove tersebut, bisa dipastikan juga berimbas pada banyaknya sumber daya ikan di sekitar Kabupaten Demak (Bappeda Kabupaten Demak, 2018). Sumber daya laut di Kabupaten Demak berupa perikanan tangkap juga cukup beragam, mulai dari rajungan, ikan karang sampai ikan pelagis. Jenis ikan yang paling banyak ditemui di Demak adalah rajungan, ikan bawal, ikan kembung, ikan layur, udang serta berbagai jenis ikan lainnya. Di sisi lain, produksi perikanan budidaya (aquaculture) paling banyak adalah jenis ikan bandeng. Hasil dan produk pengolahan ikan yang terdapat di wilayah pesisir Demak biasanya berupa ikan kering atau ikan asin, kerupuk ikan atau kerupuk udang, bandeng presto, dan juga terasi (Adhuri et. al., 2018).

Sebagai salah satu kabupaten terpadat di wilayah Jawa Tengah, jumlah penduduk di Kabupaten Demak tercatat sebanyak 1.151.796 jiwa, dengan jumlah laki-laki sebanyak 570.481 dan perempuan sebanyak 581.315 (Badan Pusat Statistik Kabupaten Demak, 2019). Dari data statistik tersebut terlihat bahwa perbandingan jumlah lakilaki dan perempuan hampir berimbang. Rata-rata penduduk Demak memiliki pekerjaan di sektor pertanian, perkebunan, peternakan, serta perikanan. Khusus untuk sektor perikanan, biasanya dilakukan oleh penduduk yang tinggal di kawasan pesisir. Aktivitas penangkapan ikan (melaut) mayoritas terdapat di 2 kecamatan, yaitu Kecamatan Bonang dan Kecamatan Wedung. Dari data yang diperoleh dari Dinas Kelautan dan Perikanan Kabupaten Demak, jumlah nelayan di tahun 2019 hanya tersisa sebanyak 8.748 orang (Dinas Kelautan dan Perikanan Kab. Demak, 2018). Jumlah ini berkurang cukup signifikan dibandingkan dengan tahun 2015. Pada saat itu jumlah nelayan mencapai 10.038 orang. Nelayan yang tersisa saat ini merupakan nelayan pandega (nelayan yang bekerja sebagai buruh atau anak buah kapal) yang dapat dikategorikan sebagai nelayan miskin (Muthmainnah et. al., 2017). Data nelayan pandega dapat dilihat pada tabel 1 berikut.
Tabel 1 Jumlah Nelayan Pandega (Sumber: Dinas Kelautan dan Perikanan Kab. Demak)

\begin{tabular}{cc} 
Tahun & Jumlah Nelayan Pandega \\
\hline 2015 & 10.038 orang \\
\hline 2016 & 8.882 orang \\
\hline 2017 & 9.318 orang \\
\hline 2018 & 9.318 orang \\
\hline 2019 & 8.748 orang
\end{tabular}

Menurunnya jumlah nelayan dari tahun ke tahun diakibatkan oleh berbagai faktor, seperti berkurangnya minat masyarakat untuk menjadi nelayan, biaya melaut yang semakin mahal, berkurangnya ikan tangkapan di laut, sampai pada perubahan iklim global. Kesemua hal ini menyebabkan masyarakat pesisir semakin rentan dengan kemiskinan. Padahal sumber livelihood mereka hanya bergantung pada hasil laut (Adhuri et. al., 2018).

\subsection{Kondisi Perempuan Pesisir Demak dalam memperjuangkan HAM dan Kesetaraan Gender}

Perempuan pesisir Demak ingin diakui sebagai perempuan nelayan. Untuk itu mereka harus mendapatkan perlindungan dari pemerintah, baik lokal maupun nasional. Hal ini pernah dikaji oleh Food and Agricultural Organization (2015) yang mengatakan bahwa pemerintah wajib memperlakukan perempuan nelayan secara baik dan adil agar hak-hak dasarnya dapat terpenuhi, seperti 1) tersedianya pemukiman yang layak, 2) akses terhadap sanitasi yang bersih dan higienis, 3) ketersediaan air minum yang aman untuk keperluan individu dan rumah tangga, 4) akses terhadap sumber energi yang terjangkau, 5) akses terhadap tabungan, kredit dan skema investasi, 6) pengakuan atas keberadaan dan peran perempuan dalam rantai nilai perikanan skala kecil, khususnya pasca panen, 7) terciptanya kondisi bebas dari diskriminasi, kejahatan, kekerasan, pelecehan seksual, dan hal buruk lainnya, 8) menghapus sistem kerja dengan paksaan, 9) memfasilitasi partisipasi perempuan dalam bekerja, 10) kesetaraan gender yang merujuk pada aturan 
CEDAW (Konvensi Penghapusan Segala Bentuk Diskriminasi Terhadap Perempuan), serta 11) pengembangan dan pendayagunaan teknologi untuk perempuan yang bekerja di sektor perikanan skala kecil. Keseluruhan poin ini bisa dicapai jika pemerintah mulai mendengarkan jaringan perempuan di akar rumput dan memprioritaskan keberadaan perempuan nelayan di Indonesia, khususnya Demak.

Perempuan pesisir Demak pada dasarnya terkenal tangguh dan berani. Mereka memiliki motivasi yang kuat untuk memperjuangkan haknya sebagai perempuan nelayan. Hanya saja, kultur religius dan adat Jawa terkadang menjadi halangan untuk memperjuangkan haknya dan mengharuskan mereka untuk lebih nrimo (pasrah). Menurut data Bahari (2018), banyak di antara perempuan nelayan yang belum merasakan kesempatan dan hak yang sama dengan laki-laki nelayan, padahal beban kerja dan tanggung jawabnya sama baik di keluarga maupun di masyarakat.

Menurut Mak Masnuah (43 tahun) perempuan nelayan yang juga menjadi pemimpin pergerakan sosial perempuan di Demak, perempuan nelayan yang terdapat di Kabupaten Demak rata-rata berumur 30 sampai dengan 55 tahun. Mereka memiliki tingkat pendidikan yang cukup rendah (mayoritas adalah tamatan Sekolah Menengah Pertama). Dengan usia terbilang produktif, mereka tetap melaut bersama suaminya meskipun di rumah juga harus mengasuh anak. Bahkan ada perempuan yang ketika masa kehamilan masih membantu suaminya melaut. Ditambahkan oleh Ibu Umi (47 tahun), umumnya perempuan nelayan di Kabupaten Demak merupakan nelayan rajungan. Mereka menangkap rajungan dengan menggunakan kapal berukuran kecil (antara 1 sampai dengan 2 GT). Selain itu, ada juga yang menggunakan gill-net, jaring kantong, serta jaring kelapan untuk menangkap ikan. Tapi tidak semua jenis ikan bisa ditangkap sepanjang tahun dan bisa dijadikan sumber mata pencaharian masyarakat pesisir Demak. Hanya rajungan, kepiting bakau serta siput laut yang jumlahnya cukup stabil dan selalu tersedia di pesisir Demak.

Menurut Dinas Kelautan dan Perikanan Kabupaten Demak (2018), komoditas hasil laut di Kabupaten Demak cukup beragam, mulai dari rajungan sampai jenis ikan pelagis. Namun, semua komoditas ini memiliki tantangan tersendiri ketika akan dijual. Harganya yang cenderung turun naik dan tingkat kesegarannya menjadi penentu di pasaran. Belum semua nelayan tersentuh bantuan, seperti cold storage, jika pun ada bantuan dari pemerintah, kerap kali listrik tidak tersedia di desa mereka. Jadi banyak sekali bantuan yang akhirnya tidak efektif dan belum tepat sasaran (Bahari, 2018).

Menurut amanat UU No. 31 tahun 2004 tentang Perikanan yang sudah direvisi menjadi UU No. 45 tahun 2009, disebutkan bahwa "nelayan merupakan orang yang memiliki mata pencaharian dengan melakukan penangkapan ikan". Artinya, siapa pun yang melakukan kegiatan penangkapan ikan (selama tidak bertentangan dan melanggar aturan hukum yang ada) dapat disebut sebagai nelayan, baik itu laki-laki maupun perempuan. Pada tahun 2016, Pemerintah Republik Indonesia kembali mengeluarkan regulasi bagi nelayan, terutama mengenai perlindungan dan pemberdayaan nelayan. Regulasi yang dimaksud adalah UU No. 7 tahun 2016. Dengan dikeluarkannya regulasi ini seharusnya pemerintah menyebutkan klausul khusus mengenai keberadaan perempuan yang bekerja sebagai nelayan. Namun, pada kenyataannya mereka masih dikategorikan sebagai anggota dalam rumah tangga nelayan.

Pilihan menjadi perempuan nelayan di negara berkembang seperti Indonesia yang masih sarat akan isu ketimpangan HAM dan gender merupakan pilihan yang cukup berat. Hal ini bukan hanya dilihat dari beban kerjanya, namun dikarenakan masih tidak adanya jaminan serta pengakuan oleh pemerintah. Dengan menjadi nelayan, artinya perempuan harus siap dengan semua risiko yang akan ditimbulkan ketika menjalani kegiatan penangkapan ikan, 
khususnya melaut. Risiko inilah yang diambil oleh nelayan perempuan di pesisir Demak. Untuk meminimalisir risiko ketika melaut, perempuan nelayan membutuhkan jaminan kesehatan dan keselamatan kerja dari pemerintah. Tapi tentu untuk mendapatkan jaminan kesehatan dan keselamatan kerja ini mereka harus melakukan banyak hal. Salah satunya adalah membentuk organisasi atau kelompok agar keberadaan mereka diakui secara hukum. Selain itu, agar mereka bisa mengakses berbagai bantuan serta program pelatihan yang dimiliki oleh pemerintah (Ambari, 2019). Hal ini yang kemudian menjadi dasar tuntutan perempuan nelayan di Kabupaten Demak serta beberapa wilayah lain di Indonesia. Mereka merasa bahwa hak asasi dan kesetaraan gender harus diperjuangkan.

\subsubsection{Kesadaran akan Hak Asasi Manusia}

Dalam Deklarasi Universal Hak Asasi Manusia (UDHR) terutama Pasal 1 sangat jelas disebutkan bahwa "semua manusia dilahirkan merdeka dan setara martabat dan haknya". Hak asasi manusia, terutama hak untuk hidup, merupakan hak dasar yang melekat di diri setiap individu dan tidak bisa dipisahkan. Oleh karena itu, setiap individu tidak bisa serta merta menyerahkan dan memberikan hak asasi manusia mereka pada pihak lain, dan pihak lain pun tidak bisa merenggutnya (Inter Agency Standing Committee, 2006). Hak asasi manusia mendapat perlindungan hukum yang pasti, baik di level nasional maupun internasional. Di tingkat nasional, UUD 1945 telah dengan tegas menyatakan tentang adanya pengakuan terhadap prinsip persamaan bagi seluruh warga negara tanpa kecuali. Prinsip persamaan ini menghapuskan diskriminasi, karenanya setiap warga negara mempunyai hak yang sama di hadapan hukum dan pemerintahan tanpa memandang agama, suku, jenis kelamin, kedudukan, dan golongan. Selain UUD 1945, terdapat beberapa instrumen hukum lainnya yang memiliki substansi untuk melindungi HAM, yaitu UU No. 39 tahun 1999 tentang Hak Asasi Manusia (HAM), UU no. 11 tahun 2005 tentang Pengesahan Kovenan Internasional akan Hak-Hak Ekonomi, Sosial dan Budaya, serta UU No. 12 tahun 2005 tentang Pengesahan Kovenan Internasional akan Hak-Hak Sipil dan Politik.

Dalam hukum Hak Asasi Manusia (HAM), setiap negara wajib untuk menghargai, melindungi, dan memenuhi hak asasi manusia. Meskipun hukum internasional dan hukum nasional telah menjamin kesetaraan hak bagi kaum perempuan dan kaum laki-laki, namun ada saja permasalahan yang timbul terhadap kaum perempuan baik secara de jure (dalam hukum) maupun secara de facto (dalam praktiknya). Selain itu, dengan adanya konvensi tentang Penghapusan Segala Bentuk Diskriminasi terhadap Perempuan (CEDAW) turut memperkuat ketentuan tentang hak asasi kaum perempuan, dan konvensi ini bertujuan untuk menghapus diskriminasi terhadap perempuan dan mencapai kesetaraan gender. Konvensi CEDAW telah diratifikasi oleh 183 negara di dunia dan menjadi milestone bagi setiap negara untuk menegakkan hukum dan melindungi kaum perempuan (CEDAW, 1979). CEDAW mendefinisikan diskriminasi terhadap kaum perempuan dalam terminologi "semua pembedaan, pengecualian atau larangan yang dibuat berdasarkan jenis kelamin yang berimbas pada terhambatnya proses pengakuan kaum perempuan di bidang politik, ekonomi, sosial, budaya, sipil ataupun bidang-bidang lainnya". Jadi esensinya negara harus mampu melindungi perempuan dari tindakan diskriminasi, memberikan kesempatan alternatif pada perempuan untuk berkembang, melakukan pola restrukturisasi pada aspek sosial dan budaya, serta yang terpenting memastikan kesetaraan dalam 
kehidupan publik bagi kaum perempuan (Resureccion, 2009).

\subsubsection{Kesetaraan Gender Perempuan Nelayan}

Selama beberapa dekade terakhir, istilah gender telah cukup akrab dalam konstruksi kehidupan sosial masyarakat. Di Indonesia, hampir semua program pemberdayaan sosial yang dilakukan oleh pemerintah, maupun program pemberdayaan yang diinisiasi oleh organisasi masyarakat sipil telah banyak bersinggungan dengan masalah gender. Pada masyarakat Indonesia, masih terjadi kerancuan dan keambiguan tentang hal yang dimaksud dengan konsep gender serta korelasinya dengan usaha perjuangan kaum perempuan. Istilah gender berasal dari bahasa Inggris. Jika ditelaah, istilah gender di dalam kamus, belum ada pembedaan jelas antara kata seks (jenis kelamin) dan gender. Selain itu, belum ada penjelasan yang singkat dan mudah dipahami oleh masyarakat umum tentang konsep gender dan mengapa konsep tersebut penting untuk memahami ketidakadilan sosial. Dengan kata lain, timbulnya kerancuan itu disebabkan oleh kurangnya penjelasan tentang kaitan antara konsep gender dengan masalah ketidakadilan lain yang ditimbulkannya. Pendapat tersebut juga didukung oleh Suryanto (2010), yang mengatakan bahwa sejarah perbedaan gender (gender differences) antarmanusia, tepatnya kaum laki-laki dan kaum perempuan, telah terjadi cukup lama dan melalui proses yang panjang. Jadi, perbedaan gender terbentuk karena banyak hal, di antaranya dibentuk, disosialisasikan, diperkuat, bahkan dikonstruksi secara sosial atau kultural, baik melalui ajaran keluarga, keagamaan, maupun negara. Melalui proses panjang tersebut, proses sosialisasi akhirnya diejawantahkan menjadi ketetapan Tuhan yang seolah-olah bersifat biologis dan ajeg (tidak bisa diubah), sehingga perbedaan gender dianggap dan dipahami sebagai kodrat yang melekat pada diri laki-laki dan perempuan. Namun, dalam tulisan ini, istilah istilah gender mengacu pada perbedaan sosial antara kaum laki-laki dan kaum perempuan yang sudah melekat dalam kehidupan sejarah dan budaya manusia. Gender juga menjadi titik penentu dalam pembagian peran, kekuasaan serta akses dan pengelolaan sumber daya bagi laki-laki dan perempuan. Permasalahan peran, kekuasaan dan sumber daya bagi kaum perempuan dan laki-laki tentunya juga menimbulkan gap atau kesenjangan

Diskusi tentang kesetaraan gender tidak bisa dilepaskan dari peran perempuan di dalam masyarakat, terutama peranan mereka di industri strategis, seperti industri barang dan jasa, pertanian, perkebunan serta perikanan. Di Indonesia, dengan wilayah laut dan pesisir terbentang luas, perempuan memiliki peranan penting dalam kegiatan perikanan. Menurut Kawarasuka (2010) kegiatan menangkap ikan, terutama kegiatan penangkapan komersial masih didominasi oleh laki-laki. Sementara perempuan cenderung lebih banyak terlibat dalam proses pengolahan serta pemasaran ikan. Belum banyak data mengenai pekerja perempuan yang berkontribusi di sektor perikanan. Setelah itu, Harper (2013) juga menyatakan bahwa wanita yang terlibat dalam perikanan skala kecil cukup signifikan, yaitu sebanyak $56 \%$ di seluruh dunia. Tapi sayangnya, perempuan nelayan yang terdata hanyalah perempuan yang berperan sebagai pengolah dan pemasar hasil ikan, bukan perempuan yang berperan sebagai nelayan tangkap. Permasalahan perempuan nelayan masih dianggap tabu di seluruh dunia.

Selain itu, kajian yang dilakukan oleh FAO (2017) tentang perempuan nelayan skala kecil menyebutkan bahwa dalam rantai nilai pasar dan profit, perempuan nelayan seharusnya memiliki akses dan kontrol yang sama dengan nelayan lainnya. Masih jamaknya pandangan mengenai perempuan nelayan sebagai pekerja berstatus rendah, tidak terampil, dan tidak layak dibayar dengan adil, haruslah dikaji ulang oleh semua pihak, baik masyarakat, budaya patriarki yang mengakar, serta pemerintah sebagai pembuat kebijakan. Karena 
pandangan inilah yang ujungnya akan membuat stigma dan diskriminasi terhadap mereka terus terjadi sampai saat ini.

Di Indonesia, terutama Kabupaten Demak, laki-laki nelayan selalu mendapatkan peluang informasi lebih besar dibandingkan nelayan perempuan. Hal ini jelas terlihat ketika ada program bantuan untuk masyarakat nelayan, yaitu pihak lakilaki lebih diutamakan. Padahal perempuan sebagai anggota masyarakat mempunyai hak dan kewajiban yang sama dengan laki-laki. Selama ini akses perempuan dalam pengembangan usaha perikanan sering terganjal oleh perbedaan serta ketimpangan gender yang diberlakukan pemerintah sendiri. Pemerintah melalui UU No 7 Tahun 2016 tentang Perlindungan dan Pemberdayaan Nelayan, Pembudidaya Ikan dan Petambak Garam, hanya mengakui kontribusi perempuan dalam rumah tangga nelayan. Padahal perempuan nelayan selama ini berjuang untuk menjadi sejajar dengan nelayan laki-laki dalam memastikan kebutuhan rumah tangga, komunitas, dan bangsa.

Kesadaran para perempuan nelayan di Kabupaten Demak akan haknya telah dimulai dengan cara membentuk kelompok dan masuk ke dalam keanggotaan PPNI (Persaudaraan Perempuan Nelayan Indonesia), dan hal ini telah diadvokasi sejak lama oleh KIARA (Koalisi Rakyat Untuk Keadilan Perikanan), PPNI serta LBH Apik. Dengan adanya kesadaran akan kesetaraan gender pada perempuan nelayan, berarti mereka memiliki hak perlindungan sama seperti yang dimiliki oleh nelayan laki-laki. Hak perlindungan yang dimaksud yakni jika terjadi kecelakaan atau musibah ketika sedang melaut, maka mereka akan mendapat bantuan asuransi nelayan. Untuk memperoleh asuransi nelayan, maka para perempuan nelayan harus memiliki kartu nelayan (Pujirahayu et. al., 2018). Peraturan mengenai kartu nelayan telah diatur dalam pasal 3 Peraturan Menteri Kelautan dan Perikanan Nomor 16/PERMEN-KP/2016, dan fungsinya adalah sebagai berikut.
1. Sebagai simbol identitas profesi nelayan.

2. Sebagai basis data untuk memudahkan perlindungan dan pemberdayaan nelayan.

3. Untuk memberikan kemudahan dalam pembinaan nelayan.

4. Untuk memberikan kemudahan dalam pelaksanaan program Kementerian Kelautan dan Perikanan.

Selain itu, dengan memiliki kartu nelayan, artinya mereka berhak untuk mendaftar program asuransi nelayan yang preminya akan dibayar oleh pemerintah. Hal ini tercantum dalam pasal 12 Peraturan Menteri Kelautan dan Perikanan Nomor 18/PERMEN-KP/2016 tentang Jaminan Perlindungan Atas Risiko Kepada Nelayan, Pembudidaya Ikan dan Petambak Garam, yang berbunyi "Bantuan pembayaran premi asuransi perikanan atau asuransi jiwa diberikan kepada nelayan kecil dan nelayan tradisional yang memenuhi persyaratan berikut.

1. Memiliki kartu Nelayan.

2. Berusia paling tinggi 65 tahun.

3. Tidak pernah mendapatkan program asuransi dari kementerian, pemerintah provinsi, pemerintah kabupaten/kota, atau pernah mendapatkan program asuransi dari kementerian, pemerintah provinsi, pemerintah kabupaten/kota namun polis asuransinya telah berakhir masa berlakunya atau jenis risiko yang dijamin berbeda.

4. Tidak menggunakan alat penangkapan ikan terlarang.

Kedua PERMEN di atas menyebutkan profesi "nelayan" secara umum, artinya jika mengacu pada aturan tersebut yang berhak memiliki kartu nelayan tidak dibatasi oleh suku, agama, ras, golongan, serta gender. Seharusnya, siapapun yang menjadi nelayan, pembudidaya ikan, petambak garam berhak mendapatkan kartu nelayan. Artinya, PERMEN ini perlu direvisi sehingga bisa mengakomodir kebutuhan semua nelayan 
tanpa pandang bulu sesuai dengan hak asasi manusia. Pada tahun 2017, Presiden Joko Widodo melalui Kementerian Kelautan dan Perikanan mengeluarkan Peraturan Menteri Kelautan dan Perikanan Nomor 39 tahun 2017 tentang penggantian Kartu Nelayan dengan Kartu Kusuka (Kartu Pelaku Usaha Kelautan dan Perikanan) yang tidak hanya berfokus pada kesejahteraan nelayan tangkap, tapi juga pembudidaya ikan, petambak garam, pengolah ikan, pedagang ikan, dan pemasar produk perikanan antarpelabuhan. Kemudian, berselang 2 tahun berikutnya, PERMEN ini diubah menjadi Peraturan Menteri Kelautan dan Perikanan Nomor 42 tahun 2019. Banyaknya peraturan yang berubah dalam ruang lingkup kelautan dan perikanan yang secara langsung melibatkan nelayan belum sepenuhnya mampu menyuarakan hak perempuan nelayan.

Sumirnya regulasi yang ada disebabkan banyak hal, salah satunya adalah keterbatasan dan minimnya pemahaman pembuat kebijakan akan prinsip gender equality serta peranan perempuan dalam kegiatan perikanan (Ogden, 2017). Padahal untuk menciptakan regulasi yang inklusif dan responsif gender harus bisa mengakomodir kebutuhan semua pihak, baik laki-laki, perempuan, atau kaum marginal lainnya.

\section{Kesimpulan}

Kehidupan di pesisir Indonesia, terutama di Kabupaten Demak sangat berkorelasi dengan kemiskinan. Dibutuhkan peran dan kontribusi perempuan pesisir untuk mengatasi permasalahan ini. Perempuan pesisir tidak bisa berdiam diri di rumah. Mereka secara langsung harus terlibat dalam aktivitas kelautan dan perikanan, baik di ranah domestik maupun ranah produksi. Perempuan pesisir di Kabupaten Demak sudah sangat dekat dengan aktivitas kelautan dan perikanan sedari dahulu, bahkan ada yang menjalani profesi sebagai nelayan. Menjadi nelayan adalah pilihan mereka karena ingin membantu perekonomian keluarga dan melepaskan diri dari belenggu kemiskinan. Perempuan tangguh ini tidak melaut sendiri, melainkan bersama suaminya ataupun rekan perempuan lainnya. Meskipun pekerjaan menjadi nelayan dan menangkap ikan di laut merupakan domain laki-laki, namun perempuan juga memiliki andil besar dan telah membuktikan dirinya bisa berkontribusi dan sejajar dengan nelayan laki-laki. Meski banyak tantangan dari sisi budaya yang masih memandang perempuan sebagai manusia kelas dua, serta nuansa religiositas yang kental akan nilai Islam, namun mereka tetap berusaha untuk menciptakan keadilan melalui pergerakan sosial yang dibantu oleh PPNI, Kiara, LBH Apik, serta pergerakan grass-root di Kabupaten Demak, yaitu lembaga Puspita Bahari.

Sebagai seorang nelayan, tentu para perempuan ini juga menginginkan pengakuan sebagai perempuan nelayan dan memperoleh haknya untuk mendapatkan Kartu Nelayan (yang saat ini telah berubah menjadi Kartu Kusuka). Hal ini mereka lakukan agar bisa mendapatkan akses atas program-program pemerintah baik program pemberdayaan (pelatihan dan bantuan alat), serta program perlindungan nelayan melalui asuransi yang menawarkan jaminan perlindungan jiwa bagi nelayan. Dengan adanya kesempatan memperoleh akses program perlindungan nelayan (asuransi nelayan), maka para perempuan nelayan telah berhasil memperoleh pengakuan kesetaraan gender. Namun demikian, sebagian masyarakat dan juga pemerintah belum sepenuhnya menerima adanya prinsip kesetaraan gender. Hal ini terbukti dengan masih banyaknya regulasi yang belum responsif gender dan masih bias kepentingan patriaki. Padahal, perempuan merupakan pembawa perubahan atau agent of change dalam masyarakat. Mereka bisa menciptakan keberlanjutan ekonomi sehingga kemiskinan bisa teratasi dan kehidupan bermasyarakat, berbangsa dan bernegara bisa menjadi lebih sejahtera.

\section{Ucapan Terima Kasih}


Terimakasih penulis ucapkan atas penelitian Riset Nasional LIPI 2018-2019 yang telah memberikan penulis kesempatan untuk melakukan penelitian tentang nelayan di 5 daerah di Indonesia, serta memberikan izin kepada penulis untuk menulis mengenai perempuan nelayan di Kabupaten Demak.

\section{Daftar Pustaka}

Adhuri, D. S., Nadjib, M., Wahyono, A., Indrawasih, R., Suryanto, J., Syafii, I., Ratri, A. M. (2018). Policy Paper: Peningkatan Kesejahteraan Nelayan dengan Pendekatan Holistik dan Kolaboratif. Jakarta

Ambari, M. (2019). Perempuan Nelayan, Profesi Berat tanpa Pengakuan Negara. Ada Apa? Retrieved from Mongabay website:

https://www.mongabay.co.id/2019/06/03 /perempuan-nelayan-profesi-berat-tanpapengakuan-negara-ada-apa/

Badan Pusat Statistik Kabupaten Demak. (2019). Statistik Kabupaten Demak Dalam Angka Tahun 2018. Demak: Badan Pusat Statistik Kabupaten Demak

Bahari, P. (2018). Laporan Sosial Perempuan Nelayan Kabupaten Demak 2018. Demak.

CEDAW. (1979). The Convention on the Elimination of all Forms of Discrimination Against Women. United State of America: United Nations General Assembly

Dinas Kelautan dan Perikanan Kabupaten Demak. (2018). Data Statistik Perikanan dan Kelautan Kabupaten Demak Tahun 2018. Demak: Dinas Kelautan dan Perikanan Kabupaten Demak

Food and Agricultural Organization. (2015). Voluntary Guidelines for Securing Sustainable Small-Scale Fisheries in the Context of Food Security and Poverty Eradication. Rome: United Nations
Food and Agricultural Organization. (2017). Handbook: Towards Gender Equitable Small-Scale Fisheries Governance and Development. Rome: United Nations

Gibson, G. (2004). The Scope For Qualitative Methods In Research And Clinical Trials In Dementia. Age and Ageing, 33(4), 422426.

https://doi.org/doi.org/10.1093/ageing/af h136

Harper, S., Zeller, D., Hauzer, M., Pauly, D., \& Sumaila, U. R. (2013). Women And Fisheries: Contribution To Food Security And Local Economies. Marine Policy, 39, 56-63. https://doi.org/doi.org/10.1016/j.marpol. 2012.10.018

Indrawasih, R. (2015). Peran Produktif Perempuan Dalam Beberapa Komunitas Nelayan di Indonesia. Jurnal Masyarakat Dan Budaya, 17(2)

Inter-Agency Standing Committe. (2017). Inter-Agency Standing Committee Gender Handbook in Humanitarian Action. United State of America: InterAgency Standing Committe

Kawarasuka, N. (2010). The Contribution of Fish Intake, Aquaculture and Small Scale Fisheries To Improving Nutrition: A Literature Review. Penang: Worldfish Center

Kementerian Kelautan dan Perikanan. (2019). Pemerintah Luncurkan Proyek Percontohan Program Satu Juta Nelayan Berbasis Tekologi Digital di Sukabumi. Retrieved from Kementerian Koordinator Bidang Kemaritiman dan Investasi website:

https://maritim.go.id/pemerintahluncurkan-proyek-percontohan-programsatu-juta-nelayan-berbasis-teknologidigital-di-sukabumi/

Koalisi Rakyat Untuk Keadilan Perikanan. (2017). Hari Nelayan 2017: Negara 
Wajib Lindungi dan Berdayakan Masyarakat Pesisir. Retrieved from kiara.or.id website: http://www.kiara.or.id/2017/04/06/harinelayan-2017-negara-wajib-lindungidan-berdayakan-masyarakat-pesisir/

Muthmainnah, M. A., \& Hapsari, T. (2017). Analisis Ekonomi Rumah Tangga Nelayan Pandega Pada Alat Tangkap Mini Purse Seine di Ppp Tasikagung Rembang. Journal of Fisheries Resources Utilization Management and Technology, 6(4). Retrieved from https://ejournal3.undip.ac.id/index.php/jf rumt/article/view/18857

Ogden, L. E. (2017). Fisherwomen-The Uncounted Dimension in Fisheries Management. Bioscience, 67(2), 111117.

https://doi.org/https://doi.org/10.1093/bi osci/biw165

Pathak, V., Jena, B., \& Kalra, S. (2013). Qualitative Research. Perspectives in Clinical Research, 4(3), 192. https://doi.org/https://doi.org/10.4103/22 29-3485.115389

Persaudaraan Perempuan Nelayan Indonesia. (2018). Laporan Tahunan Persaudaraan Perempuan Nelayan Indonesia 2018. Jakarta.

Pratiwi, A. M., \& Boangmanalu, A. G. (2017). The Existence And Power Of Fisherwomen In Morodemak And Purworejo Villages: Against Violence, Bureaucracy \& Biased Of Religious Interpretation. Jurnal Perempuan, 22(4), 295.

https://doi.org/https://doi.org/10.34309/j p.v22i 4.203

Pujirahayu, E. W., Sulaiman, S., Wijaningsih, D., Rahayu, D. P., \& Untoro, U. (2018). Perlindungan Hukum terhadap Nelayan Perempuan: Studi Kasus di Kabupaten Demak, Provinsi Jawa Tengah. MasalahMasalah Hukum, 47(2), 157-166. https://doi.org/doi:10.14710/mmh.47.2.2 018.157-166

Puspitasari, D. C. (2012). Modal Sosial Perempuan Dalam Peran Penguatan Ekonomi Keluarga. Jurnal Pemikiran Sosiologi, $\quad 1(2), \quad 69$. https://doi.org/https://doi.org/10.22146/j ps.v1i2.23445

Resureccion, B. (2009). Gender in Urban Development and Its Implication. Asian Institute of Technology Thailand 2009.

Ross, H., Adhuri, D., \& Abdurrahim, A. (2018). FishCollab A toolkit to support community and government collaboration in coastal management. Jakarta: The Capturing Coral Reef and Related Ecosystem Services. https://doi.org/10.13140/RG.2.2.20961.2 0321

Suryanto. (2010). Perbedaan Mendasar Perempuan dan Laki-Laki Dilihat dari Sisi Biologis dan Sosiologis. Yogyakarta: Media Global Wacana.

Widhyharto, D. (2015). Perempuan Sebagai Agen Perubahan Sosial-Ekonomi Masyarakat Pesisir Sekitar PLTH (Pembangkit Listrik Tenaga Hybrid) Pantai Baru, Kabupaten Bantul, Daerah Istimewa Yogyakarta. Jurnal Pengabdian Kepada Masyarakat, 1(1), 156-171.

https://doi.org/http://dx.doi.org/10.22146 /jpkm.16964

\section{PERUNDANG-UNDANGAN}

Kementerian Kelautan dan Perikanan Indonesia. Peraturan Menteri Kelautan dan Perikanan nomor 18/PERMENKP/2016. (2016). Indonesia

Kementerian Kelautan dan Perikanan Indonesia. Peraturan Menteri Kelautan dan Perikanan nomor 16/PERMENKP/2016. (2016). Indonesia

Kementerian Kelautan dan Perikanan 
Indonesia. Peraturan Menteri Kelautan dan Perikanan nomor 39/PERMENKP/2017. (2017). Indonesia

Kementerian Kelautan dan Perikanan Indonesia. Peraturan Menteri Kelautan dan Perikanan nomor 42/PERMENKP/2019. (2019). Indonesia

Pemerintah Republik Indonesia. UndangUndang nomor 39 tahun 1999 tentang Hak Asasi Manusia. (1999). Indonesia

Pemerintah Republik Indonesia. UndangUndang nomor 12 tahun 2005 tentang Pengesahan Kovenan Internasional HakHak Sipil dan Poilitik. (2005). Indonesia

Pemerintah Republik Indonesia. UndangUndang nomor 45 tahun 2009 tentang Perubahan atas Undang-Undang nomor 31 tahun 2004 tentang Perikanan. , (2009). Indonesia

Pemerintah Republik Indonesia. UndangUndang nomor 7 tahun 2016 tentang Perlindungan dan Pemberdayaan Nelayan, Pembudidaya Ikan dan Petambak Garam. (2016). Indonesia 